\title{
Montevideo: escenario de conmemoración Reflexiones sobre la organización de las fiestas patrias de la segunda mitad del siglo XIX (1858-1894) ${ }^{1}$
}

\author{
Montevideo: Stage of commemoration. Reflections on the \\ organization of the national holidays of the second half of the \\ $19^{\text {th }}$ Century (1858-1894)
}

\author{
Andrea Antuña Manganelli \\ Universidad de la República \\ Uruguay \\ https://orcid.org/0000-0002-0336-4294
}

DOI: https://doi.org/10.25032/crh.v7i12.2

Recibido: $25 / 3 / 2021$

Aceptado: $22 / 5 / 2021$

Resumen: En Montevideo las fiestas patrias de fines del siglo XIX se extendían durante cuatro días, tradición barroca heredada de la época colonial, con un programa que incluía desfiles militares, juegos, discursos de los gobernantes y Tedeums en la catedral, apoyadas de la cultura musical con funciones en los teatros. La ciudad fue el soporte para disponer la escenografía de estos festejos a través de la construcción de arquitecturas efímeras en puntos significativos de la trama urbana. Este artículo apunta a revisar la elección de las fechas de la ceremonia y el lenguaje visual desplegado mediante el cual las elites letradas pensaron la nación y pretendieron explicarla a los gobernados. Busca indagar sobre la participación de aquellos actores intermedios, artistas, talleres, artesanos, que han aportado de forma contundente con su trabajo a la puesta en escena de estas fiestas y que, en diálogo con el gobierno de turno, contribuyeron a crear espacios de circulación de discursos asociados a la búsqueda de una identidad colectiva en el contexto de consolidación de naciones tempranas.

Palabras clave: Imagen, nación, arquitecturas efímeras, conmemoración

\footnotetext{
${ }^{1}$ Agradezco las sugerencias y comentarios de los evaluadores anónimos de la Revista Claves.
} 
Abstract: In Montevideo, the national holidays of the late nineteenth century lasted four days, a baroque tradition inherited from the colonial era, with a program that included military parades, games, speeches by the rulers, and Tedeums in the Cathedral, supported by musical culture, with performances in the theaters. The city was the support to arrange the scenography of these celebrations through the construction of ephemeral architectures in significant points of the urban fabric. This article aims to review the choice of ceremony dates and the visual language displayed through which the literate elites thought about the nation and tried to explain it to the governed. It seeks to inquire about the participation of those intermediate actors, artists, workshops, artisans, who have contributed in a forceful way with their work to the staging of these festivals and who, in dialogue with the current goverment, contributed to creating spaces for circulation of discourses associated with the search for a collective identity in the context of the consolidation of early nations.

Keywords: Image, nation, Ephemeral architectures, commemoration

\section{Introducción}

Las fiestas conmemorativas desempeñaron un papel indiscutible como herramientas destacadas del poder político en el proceso de construcción de la nacionalidad oriental ya que fueron instancias privilegiadas donde se negociaron discursos y representaciones con un público activo y heterogéneo (Munilla 2013: 12). Además, sirvieron para compartir y discutir puntos de vista sobre el objeto que se recuerda en común. (Frega e Islas 2001: 5). El abordaje de la liturgia política de la segunda mitad del siglo XIX resulta clave para comprender la gestación de una nueva legitimidad donde conceptos como república y nación estaban en juego. Georges Balandier sostiene que el objetivo de todo poder político es lograr su aceptación y permanencia, no por medio de la violencia ni de la justificación racional, sino mediante la producción de imágenes, la manipulación de símbolos y la teatralización de su proyecto colectivo (1994: 18). Esto se dio en Montevideo. La ciudad cobró relevancia como soporte discursivo de las manifestaciones artísticas realizadas para tal fin, siendo pasible de ser leída como lienzo material donde se plasmaron los ideales, expectativas y esperanzas de la sociedad.

$\mathrm{El}$ arco temporal elegido no es casual. Las fiestas de 1858 fueron significativas por haber sido la primera vez que se logró vestir y ornamentar Montevideo como 
capital del Estado uruguayo independiente inaugurando a su vez, la aplicación de la ley sobre festejos patrios del 17 de mayo de 1834. Promulgada durante el gobierno de Fructuoso Rivera (1830-1834), establecía que las fiestas se harían con demostraciones solemnes en los días 4, 5 y 6 de octubre. ${ }^{2}$ La fiesta del 1894 lo fue por la fastuosidad de su decoración y su programa, enmarcada en una década signada por la modernización económica y social y el avance de una democratización efectiva en el marco de formación de los Estado nación (Caetano 2016). Colaboraron en este proceso, de la mano de una fuerte inmigración extranjera, las fiestas que realizaron las comunidades italianas en 1871 que celebró el primer año de la unificación de Italia o la española que en 1892 festejó los cuatrocientos años del descubrimiento de América.

En cada una de las instancias se eligió un pasado a rememorar a través de las representaciones, de las imágenes colocadas en los pórticos, peristilos, pabellones o altares construidos en materiales livianos. Apoyadas en una liturgia festiva programada, hicieron uso del pasado que más le convino, manipulando a través de todo el andamiaje de la fiesta su proyecto colectivo (Rilla 2008). Memoria y olvido no son conceptos neutros, y la selección de hitos, fechas e imágenes depende de los criterios de cada presente que rememora ya que el recuerdo y la expectación cubren cada momento histórico (Lowental 1998). En las elecciones de las representaciones estudiadas, en la práctica y recepción de las fiestas se manejó una artillería simbólica asociada al proceso independentista de la década del veinte y sus protagonistas y al olvido de la violencia y de la muerte. El caso de 1858 fue revelador cuando el recuerdo de las guerras de las décadas del treinta y cuarenta estaba vivo en la memoria de las personas. El análisis de esta celebración por Laura Malosetti Costa es un antecedente a destacar en el que describe la fiesta con el apoyo de prensa de la época y la imagen de la plaza Matriz plasmada en un daguerrotipo (1996).

Las fiestas de este período tuvieron en común haber sido realizadas en una ciudad sin grandes edificios, urbanísticamente precaria lo que la transformaba en escenario perfecto para bocetar en ella, en tela, cartón y yeso. Lo que no tenía en piedra, lo hizo en forma de construcciones con apariencia de arquitecturas durables, característica fundamental de la fiesta barroca, aquella que le presta atención al efecto sorprendente sobre quien las contempla. Se mantuvo de la época colonial aquel

${ }^{2}$ La Nación [Montevideo], oct. 3 al 7, 1858: 1. En este periódico está reproducida integralmente el texto de la ley sancionada por el Senado y la Cámara de Representantes. 
carácter colectivo impreso en la ritualización, en los recorridos, en el factor dinámico de los actos provocando el movimiento de la población que recorrió las calles de Montevideo generando espacios de significación que se anclaron en la memoria de los uruguayos y que hoy siguen, con algunas variantes, siendo elegidos para los mismos fines (Bonet Correa 1993; Rey Ashfield 2011).

En este marco, el abordaje de las fiestas patrias es un buen pretexto para revisar la polarización de los estudios que sitúan a las elites gobernantes y a los gobernados de uno y otro lado de la frontera, como oposición social y tener una visión más amplia, problematizando sobre la red rizomática que los intercambios y las prácticas colectivas generaron. La decoraciones, arcos triunfales, esculturas, la representaciones y fechas elegidas para cada fiesta fueron espejo de un proceso de conformación de identidad nacional en el que las comunidades extranjeras, talleres de pintura, artesanos, y obreros artísticos, entre ellos varias figuras femeninas, tuvieron un rol preponderante detrás de bambalinas y aquí, dentro del repertorio general, se pretende visibilizar.

\section{Algunos hitos, fechas y escenarios destacados}

La fiesta de 1858 tuvo en el área de la ciudad Vieja con la plaza Constitución (hoy Matriz) como epicentro, principal lugar de encuentro. El presidente en ejercicio era Gabriel Antonio Pereira. Fue un gobierno (1856-1860) heredero de sangrientas guerras civiles. Propuso seguir en la línea adherida a la política de fusión de los partidos Blanco y Colorado reclamada por distintos sectores. No obstante, no fue bien recibida por algunos integrantes del ala conservadora del Partido Colorado, que se alzó en armas al mando del Gral. César Díaz. Como consecuencia, el presidente mandó fusilar a varios jefes colorados el dos de febrero de 1858 cometiendo un controvertido crimen político que tuvo no pocas derivaciones en la historia posterior del Uruguay (Frega 2016). El objetivo del gobierno fue poner la casa en orden, normalizar su vida institucional y promover una mejora de la administración pública, por lo que celebrar las fiestas nacionales funcionó como una herramienta clave para trasmitir el mensaje sobre una ansiada unidad nacional, con la bandera de la paz, la concordia, y el recuerdo de las glorias de la gesta independentista de la década del veinte mediante una liturgia festiva muy especialmente pensada.

Estos festejos fueron significativos a razón de la profusa decoración realizada y porque fue la primera vez que se aplicó la ley de festejos patrios ya mencionada. Esta ley establecía que las fiestas se debían hacer cada cuatro años en octubre y que se 
costearían con «fondos públicos sin perjuicio de las voluntarias del vecindario en los trece departamentos existentes» (Blanco Acevedo 1968: 3). ${ }^{3}$ Los artículos 3 y 4 disponían que habría dos fiestas ordinarias, el 25 de mayo y el 18 de julio y «medias fiestas» los días 20 de febrero y 4 de octubre en los años que no hubiese «Gran fiesta». Las dos primeras fechas correspondían a la independencia de la antigua capital virreinal Buenos Aires de la metrópoli en 1810 y a la jura de la Constitución de 1830 del Estado Oriental del Uruguay. El 20 de febrero recordaba la batalla de Ituzaingó de 1827 cuando las tropas orientales participaron de la victoria sobre el ejército del Brasil y el 4 de octubre de 1828 la firma de la Convención Preliminar de Paz, las que demuestran el contexto regional que los distintos proyectos políticos fueron pensados en el marco de las independencias nacionales. No obstante, ninguna referencia al 25 de agosto en 1858, «un olvido importante de nuestros legisladores» declaraba el jefe político de la ciudad, Luis de Herrera (1806-1869). ${ }^{4}$ La lectura del corpus completo de las fechas elegidas a colocarse en las decoraciones dio cuenta de los bordes imprecisos de las bases en que se apoyó la liturgia festiva, prueba de ello fue la ausencia del 25 de mayo en la construcción visual de la fiesta aunque se precisara su festejo en la ley de 1834. Por otra parte, el 25 de agosto tuvo que esperar al gobierno de Bernardo Berro (1960-1964), para ser declarada la Gran Fiesta de la República a celebrarse los días 18, 19 y 20 de abril a partir de 1862, derogándose la ley del 34. El 25 de agosto fue una fecha nómade. Fue recién en 1887 cuando se decidió, bajo el gobierno de Máximo Tajes (1886-1890) celebrar el aniversario efectivamente en agosto, ya que se entendía que las precarias arcas del Estado no estaban como para atender una fiesta en abril y que «no sería ni moral ni sensato emplear en fiestas públicas los dineros apenas suficientes para atender las obligaciones y necesidades del Estado» (Alonso Criado 1888: 111).

3 Los departamentos al 1857 eran: Montevideo, Canelones, San José, Maldonado, Soriano, Colonia, Paysandú, Cerro Largo, Durazno, Florida, Salto, Tacuarembó y Minas.

4 La Nación [Montevideo], oct. 3 al 7, 1858: 1. 


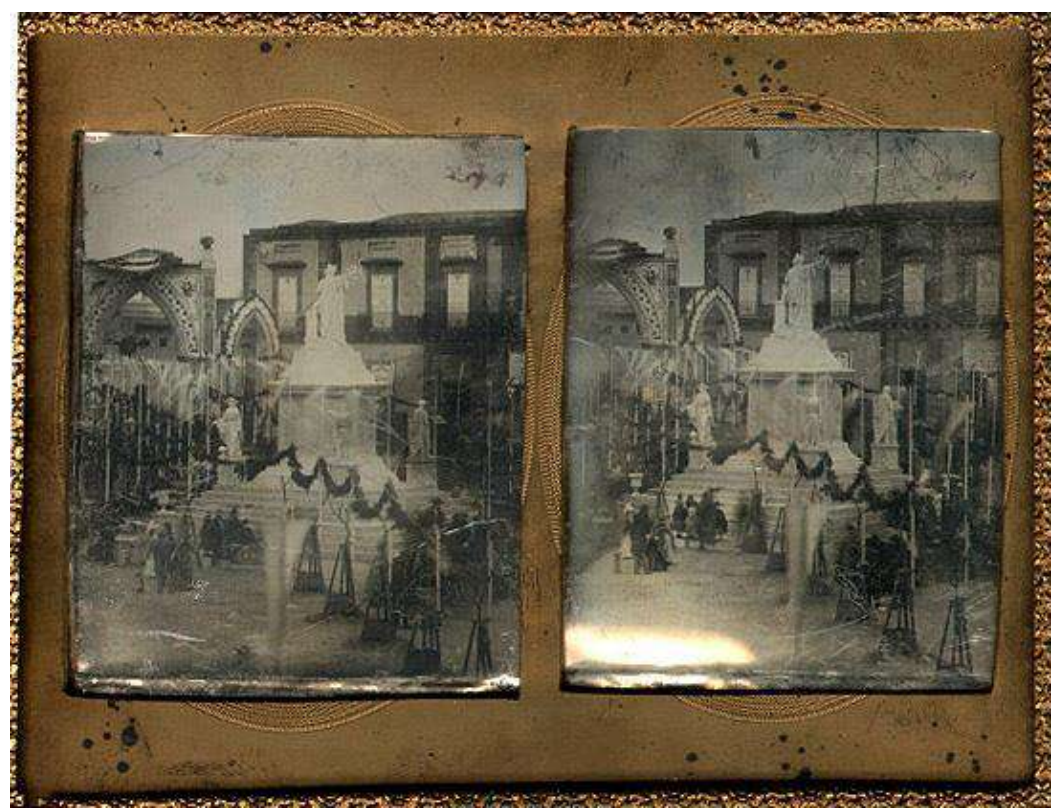

Vista de la Plaza Constitución hacia el Cabildo. Montevideo, Octubre 1858. Juan Antonio Varese, Los comienzos de la fotografía en Uruguay: el daguerrotipo y su tiempo. (Montevideo: Ediciones de la Banda Oriental, 2013) 130.5

Este repaso demuestra que los festejos se adelantaron a la legislación y la escenificación de la fiesta, si bien bajo el paragua del cumplimiento de una norma, ayudó a crear conciencia y juicios sobre el proceso emancipatorio. Las representaciones sirvieron como guías ejemplificadoras y ayudaron a forjar un relato histórico en el cual anclar los fundamentos de la construcción de la nación.

En setiembre de 1871 se realizó un arco que asemejó al arco de Tito en Roma para festejar el primer aniversario de la unificación de Italia y en 1892, a propósito de los cuatrocientos años del descubrimiento geográfico de América por Cristóbal Colón, se decoró la plaza Independencia con variados elementos, entre los más destacados dos arcos conmemoratorios desarrollados por la comunidad italiana y la española. Estos dos festejos fueron ejemplos testigo de la amplia y variada conformación de la población de Montevideo en cuanto a su origen e identidad social enmarcados en un periodo crucial en la conformación del Estado uruguayo y en la vida política y social del país. En el plano político, se pasó por formas asociadas a distintos ideales que iban desde el militarismo del coronel Lorenzo Latorre (1876-1880) y Máximo Santos (18821886), hasta los más moderados principistas civilistas entre los que se encontraban

5 El autor del daguerrotipo fue Napoleón Aubanel quien registró parte de la escenografía de ese festejo. Además este ejemplar fue exhibido en el Museo Histórico Nacional (MHN), en la exposición Hemos visto una maravilla en Montevideo en 2019. 
parte de los representantes del partidos blanco y colorado de finales de siglo o el colectivismo de Julio Herrera y Obes (1890-1894) en el que la fiesta del 92 se enmarcó.

El aluvión inmigratorio es un hito destacado de la segunda mitad del siglo XIX ya que fue un componente vital en la dinámica demográfica en el que estas dos comunidades fueron las mayoritarias y las que organizaron estas dos fiestas. Según el censo de 1884 los italianos eran 35.829 personas, un $45 \%$ de la población inmigrante, superando en diez mil a la española, en un total de extranjeros en ese año de un 44,4 \%. (Duffau y Pellegrino 2016: 197). La mayoría de las personas venían con la promesa de trabajo bajo el impulso de la Comision de Inmigración que fomentó la protección del extranjero. Mano de obra barata para la propulsión de la economía (Duffau 2011: 6). Los obreros de diferentes nacionalidades se agruparon por rubro, cuestión que desembocó en la creación de La Liga Industrial en 1879 comenzando una práctica asociativa que nucleaba oficios y bregaba por intereses comunes al gremio específico de una profesión (Beretta Curi 2012). Estos inmigrantes aportaron un amplio repertorio de formas de vida, costumbres que se arraigaron en el territorio oriental contribuyendo a la formación de una identidad colectiva nacional y fueron parte mayoritaria de la mano de obra que trabajó en la puesta en escena de estos festejos.

Con este telón de fondo se realizó el festejo de 1871, que no estuvo exento de cuestionamientos, lo que permite visualizar tensiones del entramado social de la época y contribuye a dar algunas respuestas sobre la hipótesis planteada. Por ejemplo, la Iglesia Católica, encargada de organizar algunos actos religiosos para conmemorar las fiestas patrias, con el obispo Jacinto Vera a la cabeza, manifestó su malestar porque entendía que se lastimaba simbólicamente al Papa, exhortando a los feligreses a la oración. Esto se enmarcó en el incremento del debate, que se intensificaría en los noventa, sobre el alcance del catolicismo, iniciado varios años antes, apareciendo en escena grandes figuras que colocaron al racionalismo en la otra punta de la discusión con José Pedro Varela como principal vocero. Desde La revista literaria, Varela expuso las razones sobre la elección de los ideales ilustrados para el progreso de la nación criticando fuertemente la entidad eclesiástica. Debate que tuvo eco en algunos jóvenes emigrados de Italia embanderados con la causa de Garibaldi como lo eran los autores del arco colocado en 18 de Julio, Eugenio Francisco Baroffio (Veppo, 1856-Montevideo, 
1925), padre del arquitecto Eugenio P. Baroffio, y Carlo Corsetti (Feltre, península italiana, 1823-Buenos Aires, 1903). ${ }^{6}$

Es importante destacar en este contexto una voluntad clara de fortalecer la unidad de la Iglesia y eliminar la tendencia masónica (Ardao 2013: 131-210). La evolución de esta lucha fue la creación de la Diócesis de Montevideo en 1878 encabezada por monseñor Vera. Coincidiendo con este hecho, se produjo un nuevo impulso de la secularización cuando en 1879 se resolvió crear el Registro Civil, con lo que pasó a orbita estatal la anotación de nacimientos, defunciones y matrimonios. En este marco, la celebración de 1871 del primer aniversario de la unificación de Italia tuvo su perpetuación en los liberales uruguayos de la década del ochenta, cuando, luego de ser declarada en Italia fiesta nacional en 1888, aquí no solo fue festejada por los italianos, sino por un grupo que formó la Unión Liberal. Esta asociación llevó la bandera de la educación laica y la separación de la Iglesia del Estado y tuvo un fuerte porcentaje masón, siendo sus integrantes mayoritariamente del Partido Colorado (Ardao 2013: 215-237).

La década de 1890 encontró al país con varias asimetrías. El plano económico y social mejoraba, pero en lo político se avanzaba lento hacia una democracia efectiva. Bajo la presidencia de Herrera y Obes nació el concepto de la influencia directriz, la cual proponía que el gobierno debía tener una influencia en la designación de los candidatos (Caetano 2016: 40). Las tensiones aumentaron con las guerras civiles del 94 y 97 que reclamaban la participación del Partido Blanco en el gobierno. Es de destacar que el conflicto armado de la Revolución de las Lanzas, llevado a cabo por Timoteo Aparicio (1870-1872), fue su antecedente más notorio en el cual se conquistó cuatro jefaturas políticas para este partido (Frega 2015: 81). En este contexto, la fiesta de 1892, si bien con un público concurrido, fue criticada. El periódico opositor al gobierno El Pampero, cuyo director era Juan Bonifaz y Gómez, señaló que «el pueblo parece quedar satisfecho con las diversiones después del engaño y el insulto».7

La fiesta de 1894 declaró los días 24, 25 y 26 de agosto feriados nacionales. El programa festivo incluyó los discursos de las autoridades en las plazas principales, los arribos de ministros de Brasil y Argentina, regatas y diversiones en diferentes puntos de la ciudad. El presidente Juan Idiarte Borda (1894-1897) puso de relieve el espíritu

${ }^{6}$ Suplemento dominical El Día [Montevideo], set. 19, 1943.

7 El Pampero [Montevideo], oct. 14, 1892: 1. 
optimista de aquel Uruguay en formación, recalcando la concurrencia de los ministros extranjeros «ilustres representantes a las naciones amigas y hermanas que han querido asociarse a nosotros en este día de grandes y perennes recuerdos, de grandes e intensas alegrías nacionales». ${ }^{8}$ Esto se vio reflejado en el acto de entrega de medallas a los combatientes orientales en la guerra del Paraguay por parte de los diplomáticos mencionados. Cabe destacar que la intervención de la Iglesia en estas fiestas tuvo una impronta diferente teniendo en el arzobispo Mariano Soler su vocero principal. Su discurso hizo referencia a lo nacional, incluyendo un contenido religioso-católico más elaborado que en décadas anteriores. Uno de los discursos destacados fue el Edicto Sacro Pro-Patria del 14 de agosto de 1894, en el que se exhortaba a los fieles a participar en los actos previstos como festejo de los 69 años de la independencia (Caetano 2000: 26). En el marco de debates viejos y de un proceso de secularización avanzado, con una participación menor y distinta en varios ámbitos de la vida de los montevideanos, los cimientos de la religión de la patria debían ser defendidos. La puja se vio reflejada en los editoriales de los periódicos como La Unión Colorada, que protestó por la participación de la Iglesia esperando una pronta separación, más allá de su papel especifico en las fiestas nacionales. ${ }^{9}$

Un aspecto a destacar en estas fiestas es que en un claro proceso de reivindicaciones obreras, huelgas y peticiones que llegarían a concretarse en el siglo siguiente, una nota en el periódico La Tarde significativamente informaba sobre el disfrute de la «muchedumbre enorme, que brotaba de todos los puntos de la ciudad, que hablaba y reía ruidosamente, satisfecha de gozar gratis de varias horas de jolgorios, en las que olvidaba las miserias del hogar». ${ }^{10}$ En ese sentido, la comisión de festejos aconsejó al comerciante minorista dar «algunas horas de libertades a sus empleados para que ellos también puedan participar en los regocijos de todo el pueblo». ${ }^{11} \mathrm{Un}$ temprano reclamo sobre el ocio necesario de la clase trabajadora. Así, la década del noventa fue precursora, a través de la prensa sindical y obrerista, de la creación de un partido socialista, en un debate que puso sobre la mesa diferentes corrientes, incluyendo la anarquista, que abrazaron la lucha por derechos de los más desfavorecidos. La práctica de la fiesta fue un pretexto para el goce y el reclamo

\footnotetext{
8 Discurso del presidente Juan Idiarte Borda, El Siglo [Montevideo], agosto 27, 1894: 1.

9 La Unión Colorada [Montevideo], agosto 23, 1894, n. ${ }^{\circ}$ 18, Año 1: 1

${ }^{10}$ La Tarde [Montevideo], agosto 24, 1894: 1.

${ }^{11}$ La Unión Colorada [Montevideo], agosto 22, 1894: 1.
} 
popular, enmarcadas en una década que fue germinal para la concreción de cambios políticos y sociales.

\section{Los ejecutores de la obra y escenarios elegidos}

Para que una obra se lleve a cabo muchos son los rubros a contratar. Como si se tratara de una gran obra de arquitectura, se precisó de los más variados subcontratos para realizarla y mucha coordinación para su puesta en escena. Se hará hincapié en los aspectos más destacados para cada fecha entendiendo que no es posible integrarlos a todos.

En 1858, la herencia de la estructura social jerárquica colonial se manifestó a través de las diferentes tareas asignadas a los diversos actores de la sociedad montevideana. El jefe político y de Policía de la ciudad mandaba a los jueces de paz de cada sección a que instaran a los vecinos a ornamentar su balcón, pintar su fachada o iluminar su porción de vereda. El periódico La Nación declaraba: «Ha sido práctica en otros años que cada uno de los señores jueces de Paz, ayudado por el vecindario de su sección, erigiese en ella durante la festividad un monumento, preferentemente un arco de triunfo, una pirámide o una columna iluminada durante la noche». ${ }^{12}$ La correspondencia entre el jefe político y los jueces de paz dan cuenta también de la territorialización de la fiesta, en cuanto a su costo y a las actividades desarrolladas. En la plaza de los Treinta y Tres, más alejada, se realizaron juegos populares y en la Ciudad Vieja, donde estuvieron representadas las primeras cuatro secciones judiciales, se llevaron a cabo los actos protocolares. La documentación consultada muestra que la figura del jefe político fue una de las más importantes a la hora de la organización de la fiesta. ${ }^{13}$ La Policía abandonó a partir de la década de 1850 algunas de las actividades propias de los cabildos dieciochescos y encontró nuevas funciones como la higiene, el ornato, el tránsito, el control y organización del mercado de trabajo, cuestiones relacionadas con la vecindad, etc. Esa institución se encargó de las tareas que hasta el período revolucionario habían estado en manos de intendentes, virreyes, alcaldes. Tales funciones se complementaron, conforme avanzó el siglo XIX, con tareas de seguridad interna, con funcionarios designados por el Poder Ejecutivo que tenían

12 Carta del Depto. de la Policía dirigida a los jueces de paz de Montevideo, Montevideo, set. 6, 1858. Archivo General de la Nación (agnuy), Montevideo, Fondo Policía de Montevideo, Caja 5.

${ }_{13}$ Cartas de los jueces de paz de las secciones 1 a 9 al Depto. De la Policía en respuesta a al jefe político Luis de Herrera, Montevideo, set., 1858. Agnuy, Montevideo, Fondo Policía de Montevideo, Caja 5. 
vinculación directa con la facción gobernante, por lo que era poco frecuente que continuaran en funciones una vez finalizada la actuación del gobierno de turno (Duffau 2016).

La Iglesia como institución, otro de los participantes destacados, convocaba a los fieles a través de las publicaciones propias a participar de modo militante en las fiestas patrióticas. Su escenario preferido fue el espacio interior de la catedral y la plaza Matriz. El contenido religioso de las fiestas con la realización de un Tedeum también fue una práctica heredada del período colonial convertida en ley en 1859 estableciéndose que todos los actos patrióticos debían tener un componente religioso (Caetano 2000: 23). Como se vio, en el correr del período hubo varias voces que aceptaban la participación de la Iglesia en muchos órdenes de la vida de la comunidad, mientras otras alzaban la bandera de la separación de la institución y el Estado.

A partir de lo analizado no parece casual la protesta de Jacinto Vera ya enunciada sobre el festejo de 1871 a razón de que los autores del arco, Eugenio Francisco Baroffio y Carlos Corsetti, eran integrantes de la juventud que participaba de los ideales de liberación y unidad italiana, mazzinianos y garibaldinos. Baroffio llegó a Uruguay en 1868, después de haber interrumpido sus estudios de arquitectura en la Academia de Brera (Milán), para servir a su patria en las guerras por de la Unidad Italiana, como sub teniente de la Infantería del Cuerpo de Carabineros Reales durante diez años. En Turín completó sus estudios de pintura. En el ámbito local fue reconocido por sus trabajos como escenógrafo de los principales teatros montevideanos como el Cibils, el Politeama o el Solís. (Caetano, Pérez y Tomeo 2016: 10). Carlos Corsetti se formó como pintor y emigró a América cuando se produjo la unificación del Reino de Italia bajo la dinastía de los Saboya. Radicado en Montevideo se convirtió en un destacado paisajista local. Gran acuarelista, pintó muchas vistas de Montevideo convirtiéndose sus trabajos en fuentes para la investigación histórica, ya que dibujó la ciudad con precisión. ${ }^{14}$

Ambos autores eran conocidos por su talento y trabajo en el medio cultural montevideano y formaron parte de la nómina de profesores de la Escuela de Artes y Oficios entre 1883 y 1885. Esta breve información personal permite estudiar este arco y la celebración desde el lugar de enunciación de los autores, porque aporta sustantivas

14 Los datos biográficos de Carlos Corsetti se tomaron del texto de Ernesto Beretta disponible en el sitio del MHN. http://www.museohistorico.gub.uy/innovaportal/v/64484/33/mecweb/acuarela-de-carloscorsetti?contid $=42669$ 
claves desde el ángulo de su participación dentro de la sociedad montevideana, sus vínculos laborales, a que asociaciones estaban vinculados, sus relaciones personales y profesionales que enriquecen el estudio de la significación y contextualización de esta fiesta. En este sentido algunos de sus compañeros de trabajo en la Escuela de Artes y Oficios fueron el pintor italiano Giovanni Paganucci, el litógrafo Godofreddo Somavilla, el grabador don Carlos Penoso, o el profesor de música Joaquín Salvini, entre otros. ${ }^{15}$ Esta nómina viene al caso porque a partir de la investigación sobre las fiestas de la década de 1880, la participación de la Escuela de Artes y Oficios aparece como autor relevante. No menos importante fue la intervención de sus alumnos, que a través de su relación con sus profesores formaron un grupo importante dentro del elenco de ejecutores de las fiestas. La revista La Ilustración Uruguaya, editada en la institución entre 1883 y 1885 y promovida por el gobierno de Santos, mostró claramente la participación de los niños en variados trabajos para el Estado. Entre los destacados del menú de tareas estaban aquellos concernientes a las fiestas patrias que incluyeron la realización de los tablados, las pinturas de algunas de las telas colocadas en la plaza pública y la banda musical que acompañó desfiles y discursos. Como afirma Jorge Bralich, la Escuela sirvió de taller del Estado para atender diversas necesidades en este período (51). A razón de lo analizado se desprende que los autores de los trabajos en estas fiestas no eran convocados por concursos públicos, sino que directamente se solicitaban los trabajos pertinentes. No obstante, se puede inferir la subcontratación de personal o trabajos fuera de la Escuela sabiendo que los maestros trabajaron también en el ámbito privado. En resumen, se entiende que Baroffio y Corsetti fueron figuras que coadyuvaron a generar un ámbito de sociabilidad al crear espacios de encuentro e intercambio importantes para la construcción continua de identidad nacional.

${ }_{15}$ La Ilustración Uruguaya [Montevideo], agosto 13, 1883: 2. 


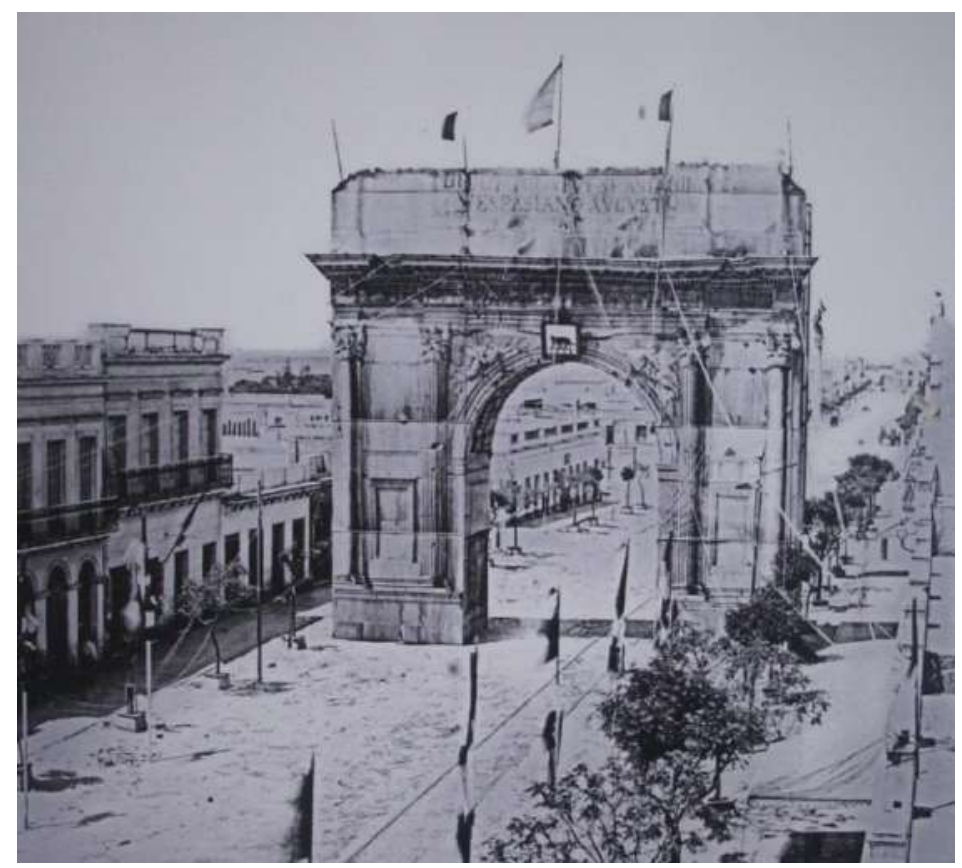

Arco realizado por Baroffio y Corsetti. Montevideo 22 de setiembre de 1871. Vista de la avenida 18 de Julio. Fuente: CDF

Capítulo aparte merecería la actuación de las mujeres en las fiestas patrias. $\mathrm{Su}$ participación, en el caso de 1894, fue importante en el repartido de socorros a los pobres durante los tres días que duraron los festejos, acción llevada a cabo por damas católicas. Además estuvieron presentes aquellas trabajadoras que confeccionaron banderines, arreglos florales, bordados de letras para banderas y carteles en tela. Un aviso publicado con el título «Fábrica de banderas de todas las naciones» por la «viuda de Alfonsi» es revelador: «Se encarga de adornos de salones para bailes, teatros, plazas, etc. Precios módicos». ${ }^{16}$

Instituciones, poder político, elite gobernante e intelectual, artistas, comerciantes, trabajadores de variados rubros se reunieron para festejar en la ciudad, convirtiendo a Montevideo en una arena cultural, lugar de germinación, de experimentación y de combate en donde se negociaron discursos asociados a la formación de estados nación a través de textos, imágenes y la práctica colectiva de mirar, leer, caminar y habitar la fiesta (Gorelik 2016).

${ }^{16}$ El Diario [Montevideo], agosto 27, 1884: 4. 


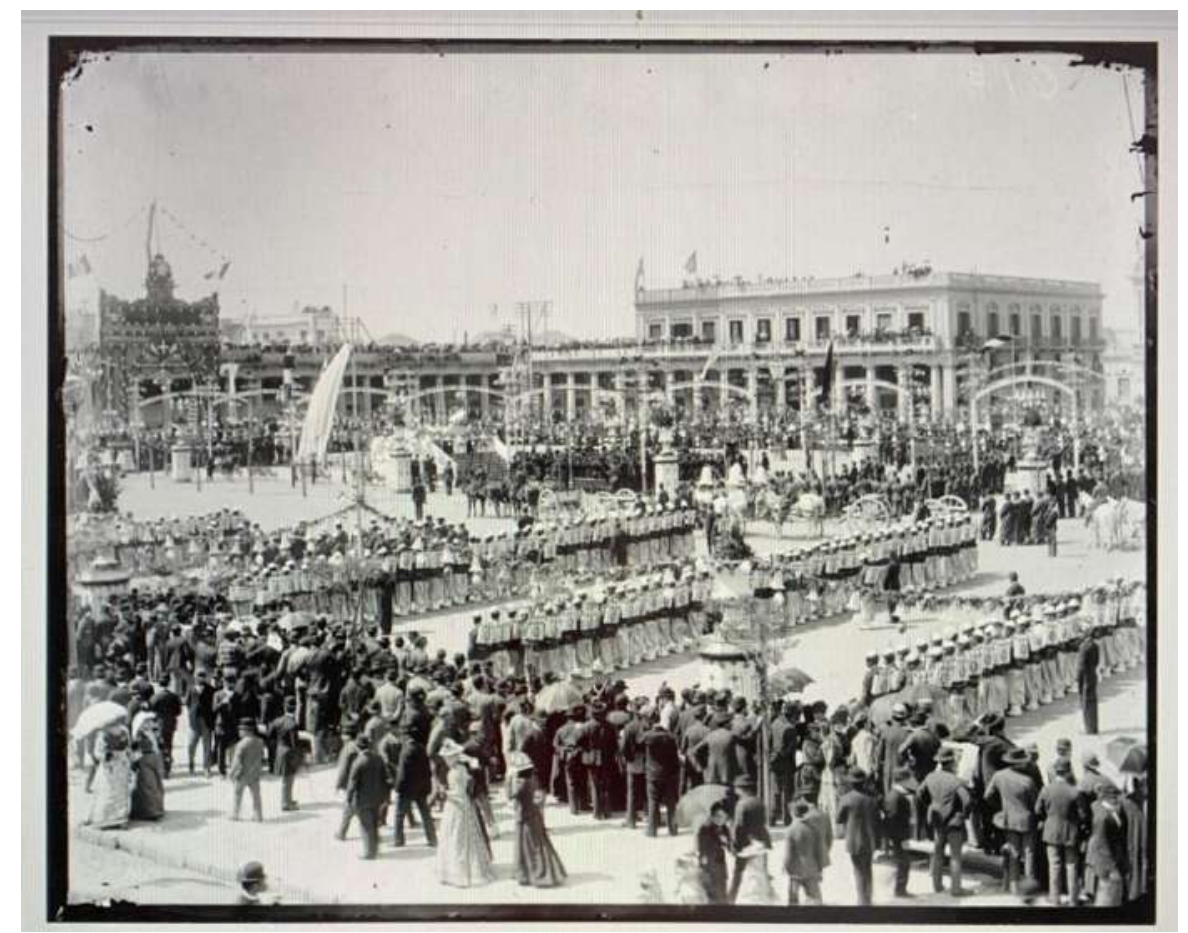

Festejos del Cuarto Centenario del Descubrimiento de América. Montevideo, 10 de octubre de 1892. Plaza Independencia. Vista hacia 18 de Julio, Arco de la comunidad Italiana. Fuente: CDF

\section{Contexto y comunicación visual de las celebraciones}

El período estudiado estuvo signado por una modalidad discursiva que tendría por principal figura a la alegoría, la cual cumplió un papel relevante en la construcción del imaginario urbano y nacional. Ofrecía una manera de imbricación entre texto e imagen en un solo espacio permitiendo la convivencia de códigos visuales que se correspondían con códigos sociales y culturales característicos de un periodo de transición histórica (Peluffo Linari 2002: 1) En la fiesta de 1858 se jugó con el uso de los emblemas convocantes de la imagen y la palabra al mismo tiempo. La fachada del cabildo como marco arquitectónico se transformó en el principal soporte dialógico del mensaje esperanzador del gobierno a través de los versos alusivos colgados en transparentes en todas las ventanas del edificio, convirtiéndose, en su conjunto en una poderosa atracción visual con un fin pedagógico moral y patriótico. El corpus completo de los poemas evocó las glorias pasadas referentes principalmente a la gesta independentista de los veinte y a la paz de octubre de 1851. Cabe destacar que tuvo todas las características del discurso fundacional en lo que tiene que ver con su funcionalidad, que excede en mucho al objetivo estético que persigue el arte. Arcos, trasparentes, esculturas en un aparente desorden propio de la emblemática barroca en la que se ensamblaron figuras impresas o decoraciones en soportes reales, utilizando 
la técnica del montaje como técnica de sintaxis visual, en la que el discurso definitivo resultó de relacionar discursos interrumpidos.

La representación colectiva, la práctica de la lectura de los habitantes de Montevideo articularon las modalidades de relación que fueron claves para la autopercepción de unidad social y, bajo el paraguas de las letras, reconocerse como pertenecientes a un mismo mundo cultural y social. La doble práctica de leer y escuchar formaba el tándem de la sociabilidad en ciernes propia del ideal civilizatorio de mediados del siglo XIX. No obstante, el grado de aceptación fue variado ya que, como afirma Mauricio Sánchez Menchero, las producciones culturales nunca son recibidas de manera uniforme por toda la sociedad, puesto que esta última está conformada por distintas subculturas, a veces antagónicas debido a la disposición de las relaciones sociales y económicas (2007: 28). En ese sentido el espacio público fue lugar de manifestación también de aquellas personas que no abrazaron el proyecto político del gobierno y expresaron su descontento, por ejemplo, en el caso de 1858, pegando carteles en las esquinas de las calles de la Ciudad Vieja con la leyenda «A las armas». Esta alusión daba cuenta del claro repudio a la política de fusión del presidente por parte de aquellos que no estaban de acuerdo con el acercamiento del mandatario a referentes del Partido Blanco. Cabe destacar que Luis de Herrera los mandó arrancar, pues podría «alarmar a algunas personas de la población».17 Los libertadores, los constitucionalistas de 1828, fueron los recordados, aunque también, de forma más sutil, José Gervasio Artigas. Cabe destacar que los usos políticos del pasado sobre estos referentes aludían a los valores republicanos y de justicia, que fueron los buscados en los mensajes escritos. Como ejemplo, uno de los trece transparentes del Cabildo, sobre el 4 de octubre de 1828, fecha de la firma de la Convención Preliminar de Paz, decía:

\author{
4 de octubre 1828 \\ Después de combatir como enemigos \\ En los campos de honor y de la gloria \\ Dan ejemplo dos pueblos a la historia, \\ Precursora de gloria y libertad \\ Fiel alianza sellando su amistad \\ El imperio acatando nuestro fuero \\ Reconoce el Estado Independiente, \\ Y Uruguay que es ya libre omnipresente \\ El olivo le ofrece a la Paz. ${ }^{18}$
}

${ }_{17}$ Carta del ministro de Gobierno Antonio Díaz, al jefe político Luis de Herrera. Montevideo, oct. 9, 1858. AGNuy, Montevideo, Fondo: Policía de Montevideo, Caja 3.

${ }^{18}$ La Nación [Montevideo], oct. 3 al 9, 1858: 1096, 3. 
La referencia al imperio de Brasil como buen receptor de la independencia del Estado oriental fue contundente. La coincidencia con lo que la ley de 1834 establecía, en cuanto a la elección de la fecha de la fiesta, calzó perfectamente con la firma de los tratados de paz de octubre 1851, fecha destacada en el repertorio de los versos. Acompañaron poemas dedicados al 14 de julio de 1825 con los nombres de los firmantes del Gobierno Provisorio o al 10 de setiembre de 1829 fecha de sanción de la Constitución por los representantes, entre los que se encontraba el presidente Pereira.

La fachada fue el plano vertical que respaldó la escultura central de la plaza que lo enfrentaba. Representó a la Constitución, y estaba flanqueada por otras cuatro que simbolizaban la concordia, la agricultura, la justicia y la industria. Cada una de ellas poseía algún elemento distintivo. Un manojo de mimbre la primera, símbolo de la unión; la hoz y las espigas para la segunda; una balanza y una espada para la tercera y la industria con una esfera en los pies, y en las manos un compás y un plano, en claro guiño hacia la logia masónica de la cual el presidente Pereira era miembro. Por otra parte, cada esquina de la plaza tenía una estructura formada por un arco principal y dos más pequeños, de estilo gótico, que contenían las inscripciones de los nombres de los departamentos de Uruguay y que fueron «pintados por los dos mejores artistas de perspectiva que asisten [sic] en Montevideo, y que son los que hacen las decoraciones para el teatro de Solís [...] que han contribuido con su buril o su pincel al mayor ornato de las fiestas».19 Era común que un mismo pintor y su taller realizaran ambas tareas, los casos de Blanes o Juan Manuel Besnes e Irigoyen son ejemplos de ello. Se construyeron peristilos en el cruce de 25 de Mayo y calle de las Cámaras (hoy Juan Carlos Gómez) y otro arco ricamente decorado en la esquina de Sarandí y Maciel, donde se ubicó la primera sede de la Universidad. Estos nodos y sus vínculos formaron parte de una red de puntos significativos dentro del área urbana, que mientras era recorrida fue conformando la geografía de los festejos. A través del estudio de su dinámica cabe la posibilidad de darle una perspectiva urbana a la historia cultural, poniendo en evidencia que las fiestas fueron momentos en que la ciudad y sus representaciones intensificaron su mutua activación (Gorelik 2016: 13).

El arco de 1871 colocado en la avenida 18 de Julio casi la plaza Cagancha fue realizado en tela e imitó formalmente al arco romano conmemorativo de las victorias del

${ }_{19}$ La Nación [Montevideo], Oct. 3 al 9, 1858: 1096, 3. 
emperador Tito. La elección formal del arco estilo clásico (romano) utilizado además en las fiestas siguientes, remitió a un sistema de simetrías y equilibrios visuales que los romanos creían haber descubierto en el cuerpo humano, geometría que era utilizada para imponer orden en el mundo que gobernaban (Sennett 1994: 110). Estas formas estuvieron asociadas a ciertos valores republicanos que se buscaron en el arte en general en el siglo XIX y Montevideo no fue la excepción. Dispuesto en forma trasversal sobre 18 de Julio, obligó a los transeúntes y carros a pasar por debajo, como lo había hecho el grupo de infantería piamontés por la puerta Pia en Roma. El arco cumplía con su sentido escenográfico original, es decir un gran pórtico dispuesto para ser traspasado, en actitud de desfile por aquellos que inauguran con su tránsito una nueva era. Metafóricamente aquí se puede adelantar la hipótesis del comienzo de un discurso de tono nacionalista en Montevideo, que tuvo sus referentes en personalidades como José Pedro Varela, Francisco Bauzá, Juan Zorrilla de San Martin, entre otros (Caetano 2000: 21). Por otra parte, se podría pensar que los autores apelaron a la memoria de los orientales para crear en ellos un instante de rememoración de la actuación de Giuseppe Garibaldi en la década de 1840 actuando en las filas del gobierno de La Defensa, vinculado al Partido Colorado, en el contexto de la Guerra Grande.

Sobresalía netamente la espectacularidad de su tamaño y el impacto visual de su expresión formal. La maestría en la pintura y proporción lograda en este arco revelan un amplio conocimiento técnico por parte de los autores, no solo de diseño, sino también de estabilidad de las estructuras, colocando cintas que hacían de tensores que llegaban a las fachadas de la avenida 18 de Julio para contrarrestar el esfuerzo horizontal del viento. A Baroffio y a Corsetti no se les escapó detalle. Las columnas pintadas en los frentes y la inclusión del símbolo de la loba en el centro apuntan con clara intención a rememorar la fundación de Roma. No obstante, como afirma Michael Baxandall, «parte del equipamiento mental con el que un hombre ordena su experiencia visual es variable, y, en su mayoría, relativa a la cultura, en el sentido en que está determinada por la sociedad que ha influido en su experiencia» (64), por lo que funcionó como un soporte escenográfico en el que se mezclaron sentidos, pero no por ello menos efectivo.

Para 1892 se preparó la zona central de Montevideo, pero también, acorde con la expansión de la ciudad, Maroñas con carreras de caballos o el barrio de la Unión con corrida de toros incluida, formaron parte del elenco de los espacios elegidos para 
festejar lo que en aquel entonces significaba el 12 de octubre: el descubrimiento de América. Dentro de los escenarios pensados para las actividades, el mar fue protagonista con la presencia de las regatas a modo de homenaje a la cruzada marítima de Cristóbal Colón. En las calles Zabala y Solís, en el muelle se reunió la gente a jugar al palo enjabonado y a disfrutar de los diferentes entretenimientos. Juegos y tiradas al agua fueron diversiones que no faltaron en esta fiesta. El puerto fue lugar privilegiado y punto de encuentro de la procesión ya que allí se congregaron el presidente en ejercicio Julio Herrera y Obes, miembros de la elite diplomática y el pueblo en general para disfrutar de los vapores, embarcaciones, barcos de todas las formas y tamaños y, el espectáculo que la Comision de las Náuticas había preparado especialmente. El 15 de octubre de ese año, el periódico L'Union Francaise comenzó su artículo a propósito de las fiestas declarando el impacto y entusiasmo de la celebración.

\footnotetext{
Ciudadanos y magistrados, laicos y eclesiásticos, civiles y militares, proletarios y financieros, ricos y pobres, todas las clases, todas las profesiones, todas las opiniones, todas las nacionalidades, incluso aquellas que habrían podido pensar que les habían recortado en exceso la porción congruente que les correspondía, estuvieron a la altura de asociarse a la glorificación de Colón y de España, y a la apoteosis de su obra común. ${ }^{20}$
}

Algunas sociedades italianas se abstuvieron de formar parte de la manifestación, entre otros motivos, por la polémica entre masones y clericales. Entre los últimos, la voz del ministro de Gobierno Francisco Bauzá se hizo sentir, en su férrea defensa de la comunidad española como aquella que echó raíces en el pueblo uruguayo contribuyendo de modo contundente, a su entender, en la generación del sentimiento de identidad nacional. Por otra parte, el presidente fue criticado desde diversos periódicos a causa de los gastos incurridos en esta celebración. Uno de ellos fue el editor el periódico El Pampero, Juan Bonifaz y Gómez, perteneciente a la de la Sociedad Filantrópica de Colón, masónica, encargada de dar comida a los pobres. El editor remarcó la gran cantidad de personas que acudieron a los puntos donde se entregaban los paquetes.

La organización de la fiesta estuvo a cargo de una comisión central conformada, entre otros, por monseñor Soler e Isidoro de María. El primero imprimiéndole el carácter eclesiástico a la fiesta y el segundo, influyente periodista e historiador que escribiera una biografía de José Artigas en la década del sesenta, nombrándolo ya allí como «fundador de la nacionalidad oriental» (De María 1957: 9). Los lugares 
privilegiados con iluminación fueron: los palacios de gobierno y municipal, la Casa de Correos, la Jefatura de Policía, el Tribunal de Justicia, la Bolsa de Comercio, las sociedades Unión Fraternal, el Centro Catalá, la Asociación Española, Operarios Italianos, la Sociedad Francesa, la Compañía de Gas, el Club Católico, la Aduana, el Centro Vascongado, entre otros. Todo esto acompañado por las cinco bandas musicales que ocupaban los balcones y además, con una escenificación de los tiempos de Colón con trajes y barco incluidos. La conjunción en un mismo espacio, la plaza Independencia, de los arcos de las dos comunidades extranjeras más importantes, fue fiel espejo de lo que sucedía en la vida cotidiana.

La fiesta y las representaciones de la fiesta nacional de 1894 tuvieron su antecedente en la década del ochenta cuando Artigas comenzó a aparecer representado. A partir del concurso de bocetos promovido por el presidente Santos para la erección del monumento al prócer a emplazarse en la plaza Independencia, publicado en la revista La Ilustración Uruguaya del 10 de mayo de 1885 varios fueron las maneras de pensar al prócer. Una de ellas fue representarlo con indumentaria militar afrancesada típico de las representaciones que las elites gobernantes urbanas quisieron mostrar, similar al que diseñara Blanes para el frontispicio de la portada de esta revista acompañado de los grandes edificios como el teatro Solís, el cabildo, el puerto, encerrados en una composición simbólica típica de las revistas ilustradas del siglo XIX (Heuguerot 2007). ${ }^{21}$

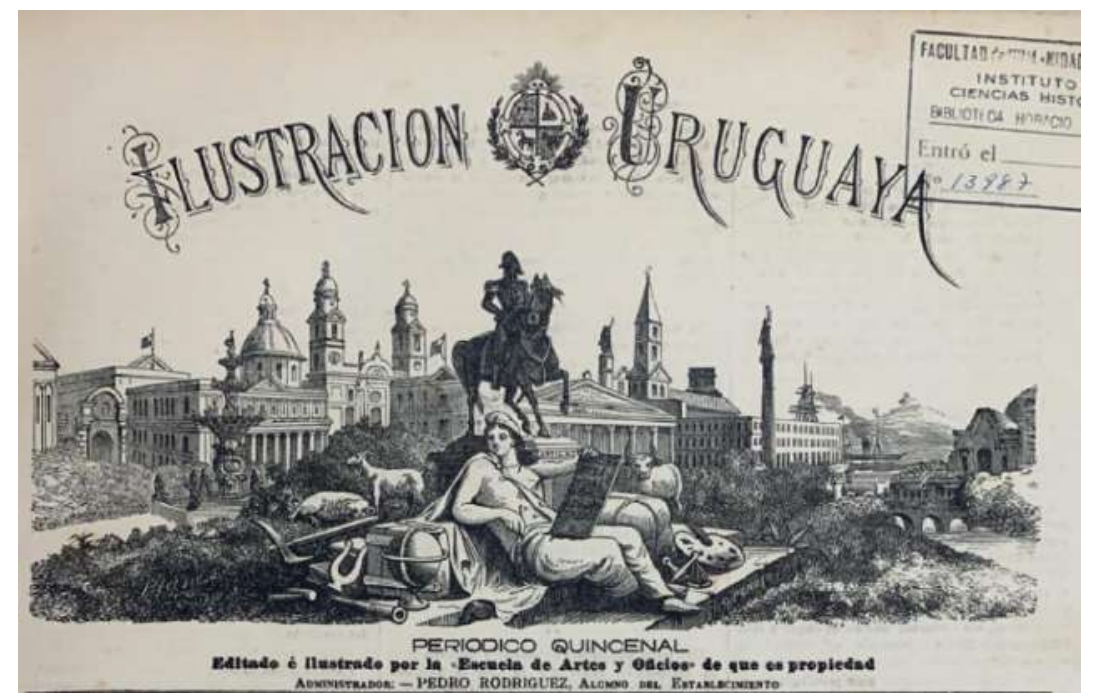

Epígrafe: «PERIÓDICO QUINCENAL. Editado é ilustrado por la Escuela de Artes y Oficios de que es propiedad. Administradores: PEDRO RODRIGUEZ, Alumno del Establecimiento». Fuente: La Ilustración Uruguaya, [Montevideo] Octubre 15, 1883, año 1, N. ${ }^{\circ} 5.1883$

${ }^{21}$ Prueba de ello es la ilustración publicada suplemento El Dominical del diario El Día, que muestra a Artigas enmarcado en cuatro pabellones nacionales que escoltan a la alegoría de la Constitución quien guía la composición. Se leía la inscripción en el frontón: «A trabajar en paz por los intereses de la patria». Suplemento dominical El Día [Montevideo], set. 19, 1943. 
En el plano económico el presidente fundó el Banco República en 1896 en formato mixto, luego de la quiebra del Banco Nacional y en el plano político se avanzaba lento hacia una democracia efectiva y un incipiente desarrollo de sindicato de trabajadores de la mano de inmigrantes. No obstante, el presidente fue una figura impopular y su gobierno estuvo plagado de conflictos. Las guerras civiles lideradas por Aparicio Saravia (1894 y 1897) son un ejemplo de ello. Su gobierno terminó con su asesinato en plena calle justamente el día de la celebración nacional en 1897. «Todo está por hacer» anunciaba el periódico La Tarde del día 24 de agosto de 1894, refiriéndose a un presente endeble, pero con la confianza en la «vitalidad del pueblo» y en el «vigor de las instituciones». ${ }^{22}$ Este periódico, cuyos redactores eran Juan Carlos Moratorio y Arturo Brizuela, ambos pertenecientes a la rama del partido colorado en contra del gobierno, criticó casi todo: la asistencia de niños, la estética de los elementos decorativos, la iluminación utilizada, hasta los fuegos artificiales. El diario El Día, con José Batlle y Ordoñez a la cabeza, no se quedó atrás. Escribió que las columnas eran «feas, pesadas, colocándose tan cerca una de la otra, hacían pensar en los preparativos de un entierro. Solo faltaba elevar banderas negras para reforzar la idea, para que se creyese que al menos un Presidente se iría a enterrar».23

No obstante, aquel 25 agosto de 1894 tuvo una plaza colmada de gente con sus mejores galas confirmadas por las imágenes que devuelven las fotografías analizadas. En la liturgia festiva de esta fecha se deben destacar la entrega de litografías a las personas con una imagen similar a la de la pintura del arco, el desembarco de los Treinta y Tres Orientales. Realizado en tela, el arco central tenía por apoyos cuatro pilastras cuadradas y en cada lado lucía una copia de la pintura mencionada de Juan Manuel Blanes, quien sería recordado como el pintor de la patria aludiendo a los temas escogidos por el artista. Los retratos elegidos para secundarlo a cada lado y encima de cada doble capitel, fueron los del Gral. José Rondeau, Eugenio Garzón, Fructuoso Rivera, Dámaso Antonio Larrañaga y Francisco Antonio Maciel. ${ }^{24}$ El acceso a la plaza por 18 de Julio o Sarandí era a través de dos obeliscos de más de ocho metros de altura de base cuadrada, y una estatua femenina sobre un pedestal que representaba la

${ }^{22}$ La Tarde [Montevideo], agosto 24, 1894, año II, N. ${ }^{\circ} 451: 1$.

23 El Día [Montevideo], agosto 27, 1894: 1.

${ }_{24}$ El Día [Montevideo], agosto 27, 1894: 1. 
independencia hacia Ciudad Vieja y otra que representaba la república o libertad hacia el oeste.

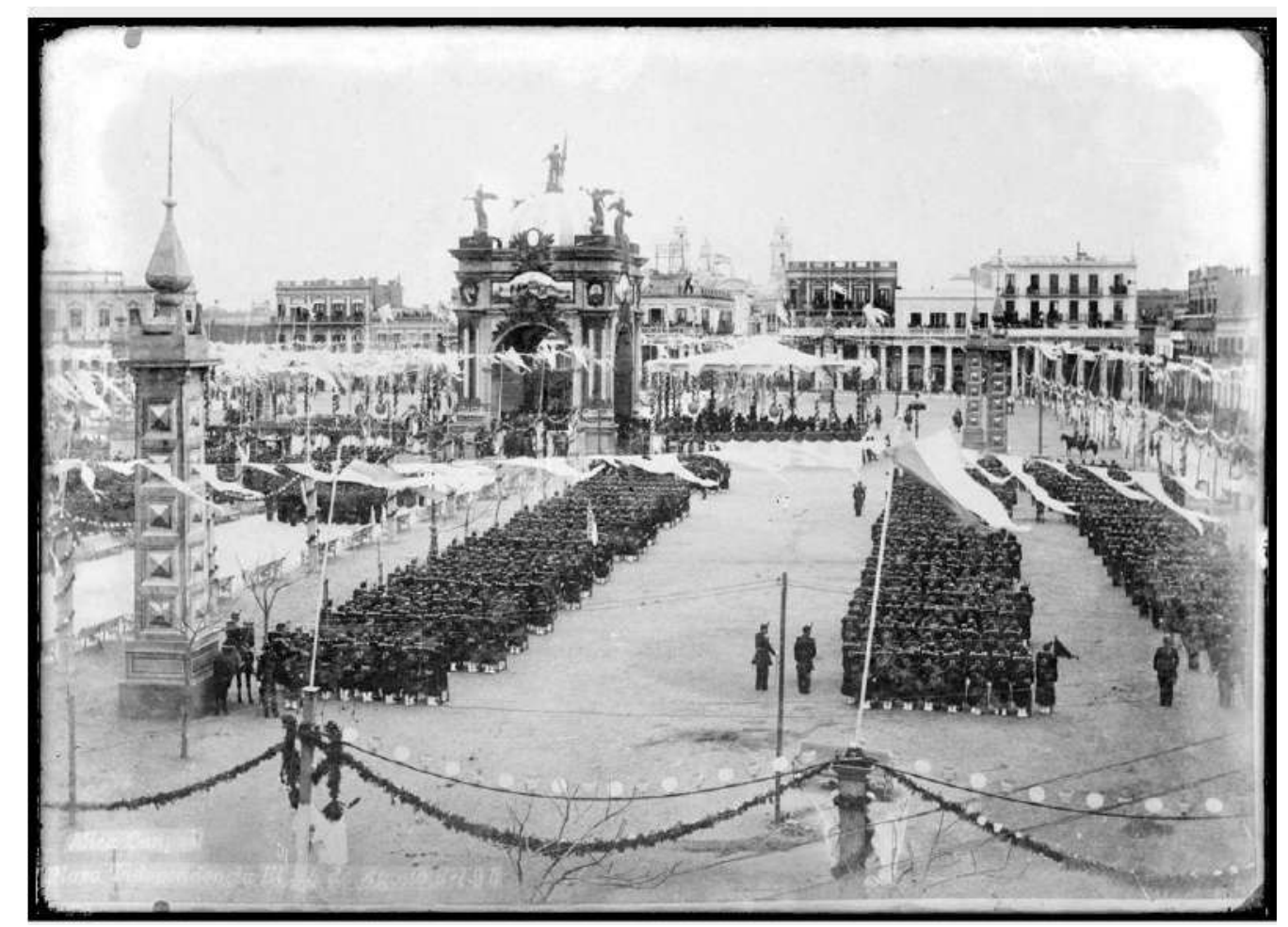

Vista de la plaza Independencia. Montevideo 26 de agosto de 1894. Fuente: CDF

Sobre una media esfera encima del arco «... coronaba aquel monumento una estatua de yeso bronceado que nos dijeron era Artigas, con el poncho terciado sobre el hombro derecho, a pesar del frio». ${ }^{25}$ Líneas de banderines, canasta de flores y guirnaldas seguían la dirección este-oeste marcando un recorrido específico dentro de la plaza, dejando a los lados espacios para las formaciones militares y luego, en los días posteriores, dejados libres para el disfrute popular. Se sumaron, además, dos tablados a los lados del arco, con sobre techos de tela a modo de carpa para los discursos oficiales. No se tienen datos sobre los autores de las pinturas de las telas, pero se puede suponer que los talleres involucrados en pintar los telones de los teatros fueran los ejecutores como ya fuera mencionado. En este marco se denota el intercambio de conocimiento de distintos oficios a través de la circulación de personas dentro de cada rubro. Las fiestas fueron un momento esperado para ser contratados, ya que funcionaba de vidriera para mostrar el trabajo de los obreros artesanos, pintores, dibujantes, litógrafos, escultores, etcétera. 


\section{El programa cultural en los teatros montevideanos durante los festejos}

La actividad artística fue notable en el período en estudio, incentivada por la inmigración italiana y francesa. Compositores, cantantes, bailarines, formaron parte de esta red rizomática de formación de identidad colectiva en fiestas patrias en el Montevideo de la época (Curotto 1969). Destacamos la gran tournée artística de 1894 que incluyó en el Solís el estreno de Tannhauser con precios que iban desde los 35 pesos en la platea y palcos bajos, hasta de o,80 en el paraíso, con el maestro Eduardo Mascheroni como director de orquesta. El Nuevo Politeama, ubicado en Colonia y Paraguay, presentaba el 22 de agosto, la compañía lírica dirigida por Beccario, Aida, anunciando la presencia del tenor Enzo Gbiliardini en el rol de Radames. El viernes 24 anunciaba la opera Mefistofeles y el 25 Otello. Se anunciaron las nuevas iluminaciones, en «teatro iluminado a giorno y nuevos adornos». ${ }^{26}$ Este anuncio de la «nueva iluminación» en esa época implicaba tener lámparas a aceite, las cuales fueron la primera causal de incendios en los teatros montevideanos. Por lo menos cuatro terminaron bajo el fuego.

El género elegido para la fiesta patria fue el operístico. El trabajo de Guillermina Guillamón arroja luces sobre la historia de la cultura musical incorporándolo como objeto de estudio que delata lugares, espacios y prácticas que van más allá de la órbita meramente musicológica (2019: 213-228). Con ello, la autora propone una reflexión en torno a las herramientas analíticas que posibilitan analizar lo musical desde las prácticas y su relación con la construcción de las representaciones en torno a ella, como los discursos que circularon y fueron apropiados a fin de impulsar la cultura musical. En este campo fue importante la labor de divulgación de la prensa de la época con la cual se puede reconstruir las trayectorias de los empresarios culturales, las representaciones de género, la formación de compañías y la programación cultural. Como elemento adicional, en la década de 1890 surgieron los conservatorios en donde los instrumentistas realizaban sus conciertos, los cuales eran los semilleros de la actividad musical (Salgado Gómez 1969: 41). En la fiesta de 1894 se presentó la soprano italiana Luisa Tetrazzini, hermana de Eva, quien ya había tenido una destacada intervención en la década del ochenta.

${ }^{26}$ El Siglo [Montevideo], agosto 22, 1894: 1. 
Las óperas que se estrenaron fueron las de Verdi, Puccini, entre otros, pero la novedad fue la irrupción del drama wagneriano. Verdi estuvo asociado al movimiento de la unificación de Italia y las letras de sus óperas, como Nabucco, sirvieron para consolidar la idea de patriotismo. La novedad de Richard Wagner fue que concibió la obra como una totalidad uniendo la orquesta con las demás artes creando una gran teatralización. Por otra parte, suscribía a los ideales del romanticismo alemán asociado en términos políticos a la idea de recuperación del espíritu originario en los pueblos germánicos. Estos autores fueron importantes en tanto le confirieron una dimensión nacional y patriótica a su música, cuestión que las elites montevideanas tomaron como herramienta para divulgar su programa de consolidación de Estado-nación. ${ }^{27}$

La difusión de los programas descriptos en esta fiesta, engloba los sinónimos de desarrollo y progreso del proyecto político y social de la elite liberal y la ópera funcionó como la herramienta para integrar a Montevideo en el círculo de las naciones civilizadas. El género lírico fue entendido por la elite gobernante como un instrumento político e ideológico en la creación y definición de la identidad nacional, por eso fue importante colocarlo expresamente como parte de la programación de la fiesta patria. La idea de civilidad asociada al buen gusto estuvo determinada desde la mitad del siglo XIX. Como afirma Antoine Hennion el gusto no es ni la consecuencia de los objetos que provocan el gusto por sí mismos, ni una pura disposición social proyectada sobre los objetos o el simple pretexto de un juego ritual y colectivo, «es un dispositivo reflexivo e instrumentado para poner a prueba nuestras sensaciones. No es un proceso mecánico, siempre es intencionado» (2010: 27). Por otra parte, la ópera constituía un espacio de sociabilidad con pretensiones aristócratas, y un lugar de difusión de la creación artística y de la moda y ofrecía un club para las elites del siglo XIX y de allí la importancia del lugar, reflejo del poder de una ciudad y del gusto de la burguesía local (Toscano y Gruzinski 2008). En este sentido es importante saber que en la circulación de la información tuvo que ver la elección de lo que se publicó. El siglo XIX estuvo asociado a un grupo de poder dentro de los editores de la prensa por lo que no es casual que se publicaran ciertos géneros y no otros. Las compañías, las prime donna, los invitados internacionales daban soporte a esta cultura de elite que era apropiada por la población conformando espacios de ejecución, escucha y sociabilidad. Los teatros,

${ }_{27}$ Se nombraron en este trabajo algunas obras operísticas entendiendo que merecería un apartado destacado que sobrepasa los estudios aquí realizados que refieran al entramado político que la elección de estas óperas supuso. 
las plazas, los hall de entrada se constituyeron en espacios fundamentales en los que se configuraron relaciones sociales, en tanto contactos, encuentros, intercambios cara a cara gestados entre dos o más personas, en definitiva espacios privilegiados donde se «entabla conversación», se profundizan vínculos, pero también se continúa un dialogo iniciado en la calle (Gayol 2007).

Cabe señalar que hubo programas en otros teatros que tenían que ver con otro tipo de obras fuera del género lírico y que fueron de gran aporte para el mismo objetivo y en esas relaciones de sociabilidad también estuvo implícito el identificarse como parte de un mismo proyecto colectivo. Esto último tiene relación con la territorialización de la cultura, es decir, la asociación de los programas exhibidos en lugares específicos, cuestión que fue común a todas las fiestas estudiadas. La ópera en los teatros del centro y los otros géneros en teatros más alejados. En ese sentido, los lugares periféricos del paisaje urbano tuvieron una intensa participación popular. Por la avenida 18 de Julio hacia el oeste llegando a la plaza de los Treinta y Tres funcionó el Gran Circo Sud Americano representando obras de pantomima como Giusseppe Garibaldi en el Astroponte. Este teatro se basaba en animaciones, números de gimnasia, pantomimas e incluían animales. Es en este campo que surgió el teatro nacional con sainetes que contaban los dramas de la vida cotidiana en el que se destacó Alcides De María, quien publicó un libro en 1894 de trescientas páginas en el que se incluían sus poesías criollas y títulos especialmente creados para la ocasión como «25 de Agosto», «Artigas» 0 《18 de Julio». ${ }^{28}$ No obstante, una peculiaridad en 1892 que refuerza la hipótesis principal de este artículo: en el teatro San Felipe, ubicado a pasos de la plaza Zabala, nodo principal de la Ciudad Vieja, se celebró una función de «la clase de color» ofreciendo una presentación muy aplaudida. ${ }^{29}$

En síntesis, el espacio del hall estuvo destinado a aquellos integrados en una lista de invitados, pero era en el espacio público, a la salida de la función cuando se socializaba con los no invitados que se recreó un espacio de intercambio donde confluían los diferentes actores sociales, donde la dicotomía entre los sujetos acreditados para estar y aquellos que no lo estaban se vincularon conformando un lugar resignificado.

${ }_{28}^{2}$ La Unión Colorada [Montevideo], agosto 22, 1894: 1.

29 El Pampero [Montevideo], oct. 14, 1892: 1. 


\section{Conclusiones}

En este breve artículo se analizaron algunos de los hitos, escenarios y representaciones de las celebraciones nacionales por entender que tuvieron un lugar destacado en el proceso de legitimación y afirmación de la nacionalidad oriental. Pensadas desde las elites gobernantes este estudio dio cuenta de la participación de otros grupos que contribuyeron en ese proceso y que no pertenecían al elenco de la clase dominante. Las representaciones elegidas permiten leer posiciones, asociaciones, grupos de poder, etc., que atravesaron la sociedad y cooperaron para la consolidación de la construcción de la identidad colectiva en el período mencionado. Dentro de este grupo destacamos, en el caso de la fiesta de 1858 los teloneros de los teatros mencionados en el periódico La Nación, los escenógrafos Baroffio y Corsetti del arco de 1871 como integrantes del repertorio de profesores de la Escuela de Artes y Oficios asociada al Estado mediante sus trabajos, red que se complementó con las actuaciones personales en otros ámbitos como asociaciones políticas y masónicas que tuvieron un importante rol desde las décadas del ochenta y noventa y las actividades culturales en los distintos teatros montevideanos.

Existió una «ciudad letrada», definida por Ángel Rama como aquella formada por una elite que regía de alguna manera la vida en comunidad que componía el anillo protector del poder y el ejecutor de sus órdenes. Una ciudad ideal que era necesario anclar y conservar más allá de su ejecución material y hacerla pervivir más allá de las modificaciones que puede infringirle el hombre común. $3^{30}$ No obstante, se nutrió y se construyó a partir del dialogo con los anillos exteriores y una de las prácticas para que esto sucediera fueron los festejos patrios en que se tomó a la ciudad como lienzo y se hizo de ella un retablo hablado. Al espacio de la plaza Constitución y sus alrededores en el Montevideo de 1858, con el eje de la avenida 18 de Julio y las nueve secciones judiciales existentes entonces, se le sumaron otras zonas a finales del siglo acompañadas por el desarrollo urbanístico, el aumento de la población y los avances tecnológicos. El desarrollo en el trasporte logró unir diversas partes de la ciudad, indispensable para crear la movilidad necesaria para llevar a la gente de un punto a otro. Se revelaron espacios que serán claves para el posterior desarrollo de geografía urbana como el hipódromo de Maroñas o la plaza de toros de la Unión. La ciudad se

30 Ángel Rama, La ciudad letrada. (Madrid: Fineo, 2009), 40. 
transformó en espacio de sociabilidad, de interacción social en la cual a través de celebración de la fiesta nacional se fueron construyendo los relatos de Nación. Las personas se apropiaron de la ciudad mediante sus movimientos. Una práctica que implicó relaciones variadas no exentas de tensiones, acuerdos, hostilidades, creando a través de ellas una geografía de la fiesta que fue desarrollándose y ampliándose en el correr del siglo. Se desplegó un repertorio simbológico que, si bien pensado por las elites letradas, mostraron un grado de aceptación variable y contestable, conformando un diálogo indispensable para la construcción de identidad colectiva.

Se demostró la indiscutida presencia y aporte de otros grupos diversos a través de sus trabajos que no formaban parte de la elite dominante. No obstante, su rol debe ser considerando dentro del marco institucional. Por eso la insistencia con los talleres, los artesanos, los carpinteros, etc., que realizaron las construcciones efímeras. Tuvieron un rol fundamental como ejecutores de los programas estético políticos, porque si bien el modelo modernizador tuvo como bandera la construcción de un nuevo orden social en el que se establecía lo prohibido y lo permitido a través de una disciplina social en aumento, la participación de estos grupos fue clave como vehículo trasmisor de ese mensaje a través de las construcciones efímeras. En ese tránsito se crearon espacios de circulación de sentidos, que completa la visión tradicional de que los discursos ligados a la construcción de la nación vienen de la mano solamente de las clases dirigentes. Si se comparan las fiestas de 1858 y la de 1894, se denotan cambios en los que se visualiza el anhelo de ese nuevo orden. Esperanza y porvenir fueron algunos de los vocablos que se repitieron en el marco de un proyecto en construcción, una maqueta del proyecto final del país basado en el progreso de la sociedad civilizada y sin guerras, en suma, una mirada auspiciosa sobre el futuro. Todo el lenguaje visual simbólico desplegado en las fiestas analizadas funcionó como instrumento para activar los mecanismos de recuerdos, memoria y evocación de un pasado glorioso.

La puesta en escena mostró los cambios y permanencias. Sobre estas últimas la más visible fue la herencia de la tradición barroca en la liturgia festiva. Al rey sobre un dosel se lo cambió por poemas, imágenes y representaciones de personajes destacados de cada presente histórico acorde con la construcción del proyecto republicano. Las construcciones efímeras funcionaron como el soporte escenográfico que ayudaba a comprender mejor la historia. La ciudad se convirtió en el espacio privilegiado para exponer ideales, expectativas, reclamos, mirar y ser mirado. Este carácter barroco de 
la fiesta tuvo su fecha de caducidad desde comienzos del siglo $\mathrm{xx}$ cuando se pensaron los grandes planes urbanísticos y los grandes monumentos se construyeron y ya no se necesitó teatralizar la fiesta con telas, cartón y yeso, porque Montevideo se armaba con arterias, vías, calles, plazas y monumentos de piedra.

Por otra parte, las fechas elegidas para la celebración fueron una herramienta para activar el recuerdo de la gente de a pie a través de los sentidos. La consigna fue anclar conceptos, hitos históricos, en una nación temprana en el caso de 1858, en el que se mezclaron discursos, pero no por ello menos efectivos. La gesta independentista de 1825 fue la protagonista en las fiestas nacionales, pero compartió cartel con muchas otras no menos importantes. Pasaron los años y a finales del siglo se consolidaba con tropiezos como fecha nacional el 25 de agosto, sin que ello fuese un obstáculo para seguir pensando los orígenes de la nación. Prueba de ello son los debates sobre el tema a lo largo del siglo xx y por qué no, en el XxI.

\section{Obras citadas}

\section{FUENTES}

\section{Archivos}

Archivo General de la Nación (Agnuy), Montevideo, Uruguay, Fondo: Policía de Montevideo.

Centro de Fotografía CDF, Intendencia de Montevideo. https://cdf.montevideo.gub.uy/

\section{Revistas:}

La Ilustración Uruguaya (1883-1885)

\section{Periódicos:}

La Nación [Montevideo, octubre 1858]

El Diario [Montevideo, agosto 1884]

El Pampero [Montevideo, octubre 1892]

L'Union Francaise [Montevideo, octubre 1892]

La Tarde [Montevideo, agosto 1894

El Día [Montevideo, agosto 1894]

La Unión Colorada [Montevideo, agosto 1894]

El Siglo [Montevideo, agosto 1894]

Suplemento dominical El Día [Montevideo, setiembre 1943]

\section{Bibliografía}


Alonso Criado, Matías. Colección legislativa de la República Oriental del Uruguay. Tomo XI. Montevideo: Manuel Alonso, 1888.

Ardao, Arturo. Racionalismo y liberalismo. Montevideo: Ediciones Universitarias, 2013.

Balandier, Georges. El poder en escenas. De la representación del poder al poder de la representación. Buenos Aires: Paidós, 1994.

Baxandall, Michael. Pintura y vida cotidiana en el Renacimiento: arte y experiencia en el «Quattrocento». Buenos Aires: Ampersand, 2016.

Beretta Curi, Alcides. Inmigración europea e industria. Uruguay en la región (18701915). Montevideo: Biblioteca Plural, 2012.

Blanco Acevedo, Pablo, «La Patria Oriental. Un debate Histórico», Cuadernos de Marcha.18. (1968).

Bonet Correa, Antonio, «La arquitectura efímera del Barroco en España», Norba. Revista de arte. 13 (1993): 23-70.

Bralich, Jorge. Orígenes de la enseñanza técnica en el Uruguay. Montevideo: Universitas, 1991.

Caetano, Gerardo. Los uruguayos del centenario: nación, ciudadanía, religión y educación (1910-1930). Montevideo: Santilana, 2000.

Caetano, Gerardo, Cecilia Perez y Daniela Tomeo, «Baroffio, arquitectura y primer batllismo: las bases físicas de un modelo de ciudadanía». Eugenio Baroffio, Gestión urbana y arquitectónica 1906-1956. ed. Ramón Gutiérrez. Montevideo: Facultad de Arquitectura, Universidad de la República Uruguay, 2016. 23-38.

Caetano, Gerardo, «La vida política» América Latina en la Historia Contemporánea. Uruguay. Reforma social y democracia de partidos. Tomo II. 1880 -1930. Ed. Gerardo Caetano. Montevideo: Planeta-Fundación Mapfre, 2016. 15-84.

Curotto, Angel, «Vida teatral montevideana», Cuadernos de Marcha. 22 (1969): 4562.

De Maria, Isidoro. Montevideo Antiguo. Tradiciones y recuerdos. Montevideo: Ministerio de Instrucción Pública y Previsión social, 1957.

Duffau, Nicolás, «Apuntes para una historia de la policía oriental. 1826-1876». Hemisferio izquierdo. (2016) https://www.hemisferioizquierdo.uy/singlepost/2016/10/o7/Apuntes-para-una-historia-de-la-Polic\%C3 \%ADa-oriental1826-1876

Duffau, Nicolás, «¿̇l infierno en Babel? Inmigración y delincuencia durante el período de la modernización en Uruguay: el caso Volpi-Patroni». Revista electrónica de la Asociación Española de Americanistas. 6 (2011). https://revistas.um.es/navegamerica/article/view/124561.

Duffau, Nicolás, y Adela Pellegrino, «Entre el cambio de modelo demográfico y la sociedad que se transforma: población y sociedad (1880 -1930)». América Latina en la Historia Contemporánea. Uruguay. Reforma social y democracia de partidos. Tomo II. 1880-1930. Ed. Gerardo Caetano. Montevideo: PlanetaFundación Mapfre, 2016. 187-236.

Frega, Ana, «La vida política». América Latina en la Historia Contemporánea. Uruguay. Revolución, independencia y construcción del Estado. Tomo 1. 1808- 
1880. eds. Gerardo Caetano y Ana Frega. Montevideo: Planeta-Fundación Mapfre, 2016. 31-85.

- Nuevas miradas en torno al artiguismo. Montevideo: Facultad de Humanidades y Ciencias de la Educación, 2001. Portal FHCE. https://www.fhuce.edu.uy

Gayol, Sandra. Sociabilidad en Buenos Aires: hombres, honor y cafés 1862-1910. Buenos Aires: Ediciones del Signo, 2007.

Gorelik, Adrián et al. Ciudades sudamericanas como arenas culturales: artes y medios, barrios de élite y villas miseria, intelectuales y urbanistas: cómo ciudad y cultura se activan mutuamente: Bogotá, Brasilia, Buenos Aires, Caracas, Córdoba, La Plata, Lima, Montevideo, Quito, Recife, Río de Janeiro, Salvador, San Pablo, Santiago de Chile. Buenos Aires: Siglo Veintiuno Editores, 2016.

Guillamon, Guillermina, «Ni «campo» ni «mundo»: Aportes y herramientas para historiar la cultura musical de principios del siglo XIX en Buenos Aires». Revista de Historiografía. 30 (2019): 213-228.

Hennion, Antoine, «Gustos musicales: de una sociología de la mediación a una pragmática del gusto». Comunicar 34 (2010): 25-33.

Heuguerot, Cristina, «Uruguay: identidad y nación en construcción». Estudios IberoAmericanos, XXXIII (2007): 76-89.

Lowenthal, David. El Pasado es un país extraño. Madrid: Akal, 1998.

Malosetti, Laura, y Miguel Ángel Cuarterolo, «De lo efímero a lo eterno. El Cabildo de Montevideo y las esculturas efímeras en un daguerrotipo de 1858». Memoria del 5to.Congreso de Historia de la Fotografía en la Argentina» (Buenos Aires, 1996): 43-49.

Munilla Lacasa, María Lía. Celebrar y gobernar: un estudio de las fiestas cívicas en Buenos Aires, 1810-1835. Buenos Aires: Miño y Dávila, 2013.

Peluffo Linari, Gabriel. «Mesa Revuelta. Iconografía y escritura en el espacio alegórico del siglo XIX». Montevideo: 25 de Octubre, 2002. Discurso. Disponible en: http://www.academiadeletras.gub.uy/innovaportal/file/72083/1/anl_peluffo discurso.pdf

Rama, Ángel. La ciudad letrada. Madrid: Fineo, 2009.

Rey Ashfield, William, «Proyecciones barrocas en el Uruguay del S. XIX: La extroversión de lo íntimo». Ilustración y Libertades 2 (2011): 9-25.

Rilla, José Pedro. La actualidad del pasado: usos de la historia en la política de partidos del Uruguay (1942-1972). Montevideo: Debate, 2008.

Salgado Gómez, Susana, «De la ópera a la música sinfónica», Cuadernos de Marcha. 22 (1969): 38-44.

Sánchez Menchero, Mauricio, «Hacia una historia cultural de las diversiones públicas: estudios culturales sobre el juego, la risa y el sobrecogimiento». Época. 26 (2007): 26-45.

Sennett, Richard. Carne y piedra : el cuerpo y la ciudad en la civilización occidental. Madrid: Alianza Editorial, 1994. 
Toscano, Verónica Zárate, y Serge Gruzinski, «Ópera, imaginación y sociedad. México y Brasil, siglo xix. Historias conectadas: Ildegonda de Melesio Morales e Il Guarany de Carlos Gomes». Histmex. 2 (2008): 803-860.

Varese, Juan Antonio. Los comienzos de la fotografía en Uruguay: el daguerrotipo y su tiempo. Montevideo: Ediciones de la Banda Oriental, 2013.

\section{Bibliografía general}

Aliata, Fernando. Carlo Zucchi: arquitectura, monumentos, decoraciones urbanas (1826-1845). La Plata: Al Margen, 2009.

Anderson, Benedict. Comunidades imaginadas: reflexiones sobre el origen y la difusión del nacionalismo. México: Fondo de Cultura Económica, 2013.

Ardao, Arturo. Espiritualismo y positivismo en el Uruguay. Montevideo: Universidad de la República, 1968.

Becker, Howard Saul. Los mundos del arte: sociología del trabajo artístico. Bernal: Universidad Nacional de Quilmes, 2008.

Beretta Curi, Alcides, y Ana García Etcheverry. El imperio de la voluntad: una aproximación al rol de la inmigración europea y al espíritu de empresa en el Uruguay de la temprana industrialización, 1875/1930. Montevideo: Fin de Siglo, 1996.

Beretta García, Ernesto. Imágenes para todos: la producción litográfica, la difusión de la estampa y sus vertientes temáticas en Montevideo durante el siglo XIX: primera etapa, de la constitución del Estado Oriental al fin de la Guerra Grande (1829-1851). Montevideo: Comisión Sectorial de Investigación Científicas de la Universidad de la República, 2015.

Bourdie, Pierre. Campo del poder y campo intelectual. Bueno Aires: Colección Argumentos, 1983.

Broquetas, Magdalena et al. Fotografía en Uruguay: historia y usos sociales, 1840 1930. Montevideo: Centro de Fotografía, Intendencia de Montevideo, 2011.

Burke, Peter. Visto y no visto: el uso de la imagen como documento histórico. Barcelona: Crítica, 2005.

Caetano, Gerardo. El Uruguay Laico. Montevideo: Editorial Uruguay, 2014.

Cortés Aliaga, Gloria y Francisco Herrera Muñoz, «Geografías urbanas, arte y memorias colectivas: El Centenario y la definición de lugar». Historia mexicana. 237 (2010): 397-438.

De Certeau, Michel. La invención de lo cotidiano. Artes de hacer. Ed. Luce Giard. México: Universidad Iberoamericana, Departamento de Historia, 2010.

Devoto, Fernando et al. L'emigrazione italiana e la formazione dell'Uruguay moderno. Torino: Edizioni della Fondazione Giovanni Agnelli, 1993.

Di Stefano, Roberto, «¿De qué hablamos cuando decimos «Iglesia»? Reflexiones sobre el uso historiográfico de un término polisémico». Ariadna histórica. Lenguajes, conceptos, metáforas. 1 (2012): 195-220.

Frega, Ana. Historia regional e independencia del Uruguay: proceso histórico y revisión crítica de sus relatos. Montevideo: Ediciones de la Banda Oriental, 2011. 
Frega, Ana, «La construcción monumental de un Héroe». Un simple ciudadano, José Artigas. Montevideo: Museo Histórico Nacional, 2014. 287-305.

Frega, Ana, y Ariadna Islas, «Identidades uruguayas, del mito de sociedad homogénea al reconocimiento de la pluralidad». Historia del Uruguay en el siglo XX (18902005), Montevideo: Ediciones de la Banda Oriental, 2007. 359-392.

Fucé, Pablo. El poder de lo efímero: historia del ceremonial español en Montevideo (1730-1808). Montevideo: Linardi y Risso, 2014.

Gellner, Ernest. Naciones y nacionalismo. Madrid: Alianza Editorial, 2008.

Gombrich Ernst H., Arte, percepción y realidad. Buenos Aires: Paidós, 1970.

Malosetti Costa, Laura. Los primeros modernos: arte y sociedad en Buenos Aires a fines del siglo XIX. Buenos Aires: Fondo de Cultura Económica, 2007.

Mauro, Diego e Ignacio Martínez, «Secularización, Iglesia y política en Argentina. Balance teórico y síntesis histórica». Historia Caribe. 14 (2015): 315-319.

Moya Blanco, Luis. Madrid escenario de España. Madrid: Instituto de Estudios Madrileños, 1952.

Munilla Lacasa, Maria Lía, «El arte de las fiestas: Carlo Zucchi y el arte efímero festivo». Carlo Zucchi y el neoclasicismo en el Río de la Plata. Bueno Aires: Instituto Italiano de Cultura de Buenos Aires, 1998. 85-90.

Oddone, Juan, Historia de la Universidad de la República. tomo I. la Universidad Vieja. 1849-1885 (Ediciones Universitarias, 2009).

Traverso, Enzo, «Historia y memoria. La interpretación del pasado como desafío político». Historia reciente. Perspectiva y desafios para un campo en construcción. Buenos Aires: Paidós, 2007. 